\title{
Studies on Management of Late Blight (Phytophthora infestans (Mont) de Bary) of Potato Using Organic Soil Amendments
}

\author{
S. H. Peerzada, K. A. Bhat and H. S. Viswanath* \\ Division of plant pathology, Sher-e-Kashmir, University of Agricultural Sciences and \\ Technology of Kashmir, $J$ \& K - 191121, India \\ *Corresponding author
}

\section{Keywords}

Late blight of

potato, Soil

amendments,

Disease incidence,

Disease intensity,

Tuber yield

Article Info

Accepted:

15 January 2020

Available Online:

10 February 2020

A B S T R A C T

Late blight, (Phytophthora infestans) of potato is the most devastating disease which was found to be prevalent in all the potato growing areas of Kashmir valley. In the present study, the effect of different amendments applied to soil singly or in combinations on late blight development and tuber yield of potato cv. Kufri Jyoti was assessed during 2016 and 2017 cropping seasons. In this experiment, seven different treatments of amendments which include vermicompost, FYM, sheep manure, Trichoderma viride, (Vermicompost + FYM), ( T. viride + FYM), (Vermicompost $+T$. viride) along with untreated/un-amended control(check) were evaluated against the incidence and intensity of the disease at two growth stages viz., during flowering and ten days before dehaulming stage of the potato crop cv. Kufri Jyoti. It was found that significant reduction in the late blight incidence and intensity was obtained with the application of different soil amendments compared to control. Soil amendment particularly with $T$. viride + FYM combination resulted in the lowest leaf blight incidence and intensity of (26.66 and 28.88\%) and (17.04 and 20.05\%) at flowering stage, and (42.21 and 44.44\%) and (23.61 and 25.90\%) at dehaulming stage, respectively compared to the incidence of 51.11 and 38.77 per cent and intensity of 79.99 and 47.93 per cent, respectively, at flowering and dehaulming stages obtained in unamended control (check) plots during 2016 and similar trend of results were obtained during 2017 where lowest disease incidence and intensity were found in the amendment with T.viride + FYM, followed by amendments with FYM or vermicompost alone compared to the un-amended control. Similarly highest tuber yield and grade A tubers were obtained with the soil amendment of T.viride + FYM followed by the amendment with FYM alone, whereas, lowest tuber yield and grade A tubers were obtained in unamended control.

\section{Introduction}

Potato (Solanum tuberosum L.) is one of the most important food crops worldwide which represents a valuable source of nutrients in a balanced diet. In terms of human consumption, the potato is the third most important food crop in the world, following only rice and wheat. Potato is also one of the important food crops in India. India stands 
second in world's potato production where it is cultivated over an area of 2.13 million hectares with a production of 43.77 million metric tonnes (Viswanath et al., 2018). The area and production of the Potato crop in Jammu \& Kashmir state are 6.9 thousand hectares and 1.27 lakh metric tonnes, respectively (Anonymous, 2015). Reports of complete field destruction due to late blight epidemics are relatively common. The fungus is responsible for global annual crop loss of US \$ 12 billion. Yield loss due to late blight in India varies from year to year and range from $20-75 \%$ The pathogen produces water soaked lesions with chlorotic borders that are small at first expand rapidly under humid conditions, blighting the entire plant in only a few days with subsequent rotting of the developing tubers resulting in heavy yield losses under favorable. (Sundaresha et al., 2015).

For more than a decade, controlling late blight has become increasingly demanding because of the emergence of new strains of the pathogen, some new strains are known to be more aggressive and resistant to the fungicide metalaxyl. Moreover, indiscriminate use of systemic fungicides especially metalaxyl (ridomil) provides chance to develop resistant strain of the fungus has been reported from home and abroad. A new sexually reproducing potato late blight $(P$. infestans) population characterised by early oosporederived epidemics is one of the most severe threats to organic potato production (Shailaba and Amarendra Kumar, 2017). So the present study was focused upon the use of organic amendments in the management of late blight disease which is environmentally a safer alternative to the use of toxic fungicides which pose great threat to the human health and also helps in preventing the development of new resistant strain to the available fungicides.

\section{Materials and Methods}

Four amendments viz., vermicompost, farmyard manure, sheep manure and Trichoderma viride, were separately amended in soil at fixed doses alone or in combination three days before planting of potato tubers of cv. Kufri Jyoti at Division of Plant Pathology, Experimentation Farm at SKUAST-Kashmir, Shalimar during 2016 and 2017 cropping seasons, laying the experiment in RBD and maintaining three replications of each treatment plot of size $2 \times 1$ metre, leaving one meter border between plots to minimize and limit the inter-plot interference. Other practices for raising the crop were followed as per the recommended package (Anonymous, 2004). The experiment include seven treatments of organic amendments which were applied either individually or in combinations along with one un-amended (un-treated) control.

The observations on late blight incidence and intensity were recorded at two stages i.e. at flowering stage and 10 days before dehaulming, and the data was statistically analyzed.

Disease incidence is calculated based on the formula

Late blight incidence $(\%)=\underline{\mathrm{n}} \times 100$ $\mathrm{N}$

Where $\mathrm{n}$ is the number of plants showing blight symptoms and $\mathrm{N}$ the total number of plants examined

Disease intensity: the observation on the extent of the foliage blighted was recorded at flowering stage and 10 days before dehaulming using the disease rating scale given by Mohan and Thind (1999) Disease Score description in terms of foliage infected $(\%)$ 
$0 \quad$ No visible

symptoms

$1 \quad 1-10$

$2 \quad 11-25$

$3 \quad 26-50$

$4 \quad 51-75$

$5>75$

The disease intensity was calculated by using the following formula

Late blight intensity $(\%)=$

Summation of numerical rating

No. of plants Examined x Maximum disease score

The tuber yields per hectare were recorded for each treatment and graded as Grade A, Grade $\mathrm{B}$ and Grade $\mathrm{C}$ as per tuber size.

The tubers categorized into different grades depending on tuber diameter.

\begin{tabular}{ll}
\hline Tuber diameter $(\mathrm{cm})$ & $\begin{array}{l}\text { Tuber } \\
\text { grade }\end{array}$ \\
\hline $8 \mathrm{~cm}$ and above & $\mathrm{A}$ \\
$4 \mathrm{~cm}$ to $8 \mathrm{~cm}$ & $\mathrm{~B}$ \\
$4 \mathrm{~cm}$ and below & $\mathrm{C}$
\end{tabular}

\section{Results and Discussion}

The effect of different amendments applied to soil singly or in combinations on late blight development and tuber yield of potato cv. Kufri Jyoti was assessed during 2016and 2017 cropping seasons. The results obtained during 2016 cropping season (Table-1) indicated significant reduction of late blight incidence and intensity with the application of different soil amendments compared to control. Soil amendments separately with $T$. viride + FYM, or FYM alone resulted in the lowest leaf blight incidence and intensity of (26.66 and 28.88\%) and (17.04 and 20.05\%) at flowering stage, and (42.21 and 44.44\%) and (23.61 and $25.90 \%)$ at dehaulming stage, respectively, compared to the incidence of 51.11 and 38.77 per cent and intensity of 79.99 and 47.93 per cent, respectively, at flowering and dehaulming stages obtained in un- amended check plots. There were corresponding yield gains with different soil amendments; amendments with $T$. viride + FYM exhibited maximum tuber yield of $185.19 \mathrm{q} / \mathrm{ha}$ followed by soil amendment with FYM alone (170.14 q/ha) compared to only $146.80 \mathrm{q} / \mathrm{ha}$ obtained in un-amended check plots. The proportions of A and B grade tubers were also more in amended soils than in un-amended soils. Amendments with $T$. viride + FYM resulted in maximum (41\%) A grade tubers followed by amendments with FYM (31\%) compared to (19.90\%) A grade tubers obtained in un amended check(table-2). Similar trend was observed during 2017 cropping season. The results (Table-3) depict significant reduction of late blight incidence and intensity with the applications of different soil amendments compared to control. Soil amendments with $T$. viride + FYM, resulted in the lowest leaf blight incidence of 22.22 per cent followed by amendments with FYM or vermicompost alone showing disease incidence of 24.44 -26.66 per cent compared to 48.88 per cent obtained in un-amended check at flowering stage. At dehaulming stage, the disease incidence was lowest (44.44 to $46.66 \%$ ) in treatments amended with $T$. viride + F Y M or FYM alone compared to 75.55 per cent, obtained in un-amended check. The disease intensity at flowering was also the minimum $(13.90 \%)$ in treatments receiving soil amendments with $T$. viride + FYM followed by those receiving only FYM amendments $(16.21 \%)$ at dehaulming stage as well, soil amendments with $T$. viride + FYM exhibited the blight intensity of 26.21 per cent followed by soil amendments with FYM alone $(28.55 \%)$ compared to un-amended check $(53.97 \%)$. 
Table.1 Effect of different soil amendments on development of late blight (Phytophthora infestans and tuber yield of potato cv. Kufri Jyoti during 2016 cropping season

\begin{tabular}{|c|c|c|c|c|c|c|}
\hline \multirow[t]{2}{*}{$\begin{array}{c}\text { Soil } \\
\text { amendments }\end{array}$} & \multirow[t]{2}{*}{$\underset{1}{\text { Dose }} \mathrm{ha}^{-}$} & \multicolumn{2}{|c|}{$\begin{array}{l}\text { Leaf blight incidence } \\
(\%)^{*}\end{array}$} & \multicolumn{2}{|c|}{$\begin{array}{c}\text { Leaf blight } \\
\text { intensity }(\%) *\end{array}$} & \multirow[t]{2}{*}{$\begin{array}{l}\text { Yield } \\
\text { qtls/ha }\end{array}$} \\
\hline & & I & II & I & II & \\
\hline Vermi-compost & 10 tons & $\begin{array}{c}31.10 \\
(30.27)\end{array}$ & $\begin{array}{c}48.88 \\
(36.77)\end{array}$ & $\begin{array}{c}22.09 \\
(27.89)\end{array}$ & $\begin{array}{c}28.22 \\
(32.05)\end{array}$ & 163.90 \\
\hline $\begin{array}{l}\text { Farmyard } \\
\text { Manure (FYM) }\end{array}$ & 25 tons & $\begin{array}{c}28.88 \\
(29.28)\end{array}$ & $\begin{array}{c}44.44 \\
(35.20)\end{array}$ & $\begin{array}{c}20.05 \\
(26.38)\end{array}$ & $\begin{array}{c}25.90 \\
(30.50)\end{array}$ & 170.14 \\
\hline Sheep Manure & 20 tons & $\begin{array}{c}33.33 \\
(31.42)\end{array}$ & $\begin{array}{c}51.11 \\
(37.88)\end{array}$ & $\begin{array}{c}26.08 \\
(30.49)\end{array}$ & $\begin{array}{c}30.12 \\
(33.17)\end{array}$ & 161.60 \\
\hline $\begin{array}{l}\text { Trichoderma } \\
\text { viride }\end{array}$ & $25 \mathrm{kgs}$ & $\begin{array}{c}37.77 \\
(32.90)\end{array}$ & $\begin{array}{c}57.77 \\
(39.45)\end{array}$ & $\begin{array}{c}26.41 \\
(30.77)\end{array}$ & $\begin{array}{c}36.40 \\
(30.90)\end{array}$ & 160.40 \\
\hline $\begin{array}{l}\text { Vermicompost } \\
+ \text { FYM }\end{array}$ & $\begin{array}{l}5+10 \\
\text { tons }\end{array}$ & $\begin{array}{c}35.55 \\
(32.13)\end{array}$ & $\begin{array}{c}53.33 \\
(38.15)\end{array}$ & $\begin{array}{c}22.30 \\
(28.13)\end{array}$ & $\begin{array}{c}34.12 \\
(35.54)\end{array}$ & 164.46 \\
\hline $\begin{array}{l}\text { T. viride + } \\
\text { FYM }\end{array}$ & $\begin{array}{l}10 \mathrm{~kg}+10 \\
\text { tons }\end{array}$ & $\begin{array}{c}26.66 \\
(28.11)\end{array}$ & $\begin{array}{c}42.21 \\
(34.53)\end{array}$ & $\begin{array}{c}17.04 \\
(24.29)\end{array}$ & $\begin{array}{c}23.61 \\
(29.01)\end{array}$ & 185.19 \\
\hline $\begin{array}{l}\text { Vermicompost } \\
+T \text {. viride }\end{array}$ & $\begin{array}{l}5 \text { tons }+5 \\
\mathrm{kgs}\end{array}$ & $\begin{array}{c}33.33 \\
(31.14)\end{array}$ & $\begin{array}{c}51.33 \\
(37.38)\end{array}$ & $\begin{array}{c}22.32 \\
(28.05)\end{array}$ & $\begin{array}{c}31.16 \\
(33.71)\end{array}$ & 159.07 \\
\hline $\begin{array}{l}\text { No } \\
\text { amendments }\end{array}$ & - & $\begin{array}{c}51.11 \\
(45.63)\end{array}$ & $\begin{array}{c}79.99 \\
(63.640\end{array}$ & $\begin{array}{c}38.77 \\
(38.47)\end{array}$ & $\begin{array}{c}47.93 \\
(43.81)\end{array}$ & 146.80 \\
\hline \multicolumn{2}{|l|}{ Mean } & $\begin{array}{c}34.44 \\
\mathbf{( 3 5 . 8 1}\end{array}$ & $\begin{array}{c}53.60 \\
(47.24)\end{array}$ & $\begin{array}{c}24.38 \\
(29.31)\end{array}$ & $\begin{array}{c}32.18 \\
(34.35)\end{array}$ & - \\
\hline \multicolumn{2}{|c|}{ S.Em+ } & 0.94 & 0.67 & 0.51 & 0.49 & 3.4 \\
\hline \multicolumn{2}{|c|}{$\mathrm{CD}(0.05 \%)$} & 2.87 & 2.03 & 0.79 & 1.08 & 10.4 \\
\hline
\end{tabular}

*Leaf blight incidence and intensity recorded at flowering (I) and 10 days before dehaulming (II) stages; data are mean of three replications.

Figures in parenthesis are arc sine transformed values

Table.2 Effect of soil amendments on tuber grades in 2016 cropping season

\begin{tabular}{|l|c|c|c|}
\hline \multicolumn{1}{|c|}{ Treatments } & \multicolumn{3}{|c|}{$* *$ Tuber grade (\%) } \\
\hline Vermi-compost & A & B & C \\
\hline Farmyard Manure (FYM) & 28.00 & 52.00 & $\mathbf{2 0 . 0 0}$ \\
\hline Sheep Manure & 31.00 & 51.00 & $\mathbf{1 8 . 0 0}$ \\
\hline Trichoderma viride & 25.90 & 51.18 & $\mathbf{2 2 . 9 1}$ \\
\hline Vermicompost + FYM & 25.00 & 51.00 & $\mathbf{2 4 . 0 0}$ \\
\hline T. viride + FYM & 29.90 & 50.10 & $\mathbf{2 0 . 0 0}$ \\
\hline Vermicompost + $\boldsymbol{T}$. viride & 41.00 & 43.51 & $\mathbf{1 5 . 4 9}$ \\
\hline No amendments & 25.00 & 53.00 & $\mathbf{2 2 . 0 0}$ \\
\hline
\end{tabular}

**Figures in parenthesis are per cent tuber grade 
Table.3 Effect of different soil amendments on development of late blight (Phytophthora infestans) and tuber yield of potato cv. Kufri Jyoti during 2017 cropping season

\begin{tabular}{|c|c|c|c|c|c|c|}
\hline \multirow[t]{2}{*}{ Soil amendments } & \multirow[t]{2}{*}{ Dose ha ${ }^{-1}$} & \multicolumn{2}{|c|}{$\begin{array}{c}\text { Leaf blight } \\
\text { incidence }(\%)^{*}\end{array}$} & \multicolumn{2}{|c|}{$\begin{array}{c}\text { Leaf blight } \\
\text { intensity }(\%)^{*}\end{array}$} & \multirow[t]{2}{*}{$\begin{array}{l}\text { Yield } \\
\text { qtls/ha }\end{array}$} \\
\hline & & I & II & I & II & \\
\hline Vermi-compost & 10 tons & $\begin{array}{c}26.66 \\
(30.97)\end{array}$ & $\begin{array}{c}51.11 \\
(45.63)\end{array}$ & $\begin{array}{c}18.09 \\
(24.99)\end{array}$ & $\begin{array}{c}31.11 \\
(18.09)\end{array}$ & 159.90 \\
\hline $\begin{array}{l}\text { Farmyard } \\
\text { Manure (FYM) }\end{array}$ & 25 tons & $\begin{array}{c}24.44 \\
(29.58)\end{array}$ & $\begin{array}{c}46.66 \\
(43.07)\end{array}$ & $\begin{array}{c}16.21 \\
(23.62)\end{array}$ & $\begin{array}{c}28.55 \\
(32.06)\end{array}$ & 175.44 \\
\hline Sheep Manure & 20 tons & $\begin{array}{c}28.88 \\
(32.47)\end{array}$ & $\begin{array}{c}53.33 \\
(46.95)\end{array}$ & $\begin{array}{c}21.19 \\
(27.34)\end{array}$ & $\begin{array}{c}34.60 \\
(35.96)\end{array}$ & 163.80 \\
\hline $\begin{array}{l}\text { Trichoderma } \\
\text { viride }\end{array}$ & $25 \mathrm{kgs}$ & $\begin{array}{c}33.33 \\
(35.17)\end{array}$ & $\begin{array}{c}57.77 \\
(49.82)\end{array}$ & $\begin{array}{c}22.31 \\
(28.03)\end{array}$ & $\begin{array}{c}38.44 \\
(38.27)\end{array}$ & 147.14 \\
\hline $\begin{array}{l}\text { Vermicompost + } \\
\text { FYM }\end{array}$ & $5+10$ tons & $\begin{array}{c}31.10 \\
(33.80)\end{array}$ & $\begin{array}{c}55.55 \\
(48.24)\end{array}$ & $\begin{array}{c}19.40 \\
(26.06)\end{array}$ & $\begin{array}{c}36.99 \\
(37.40)\end{array}$ & 156.48 \\
\hline T. viride + FYM & $10 \mathrm{~kg}+10$ tons & $\begin{array}{c}22.22 \\
(27.86)\end{array}$ & $\begin{array}{c}44.44 \\
(41.79)\end{array}$ & $\begin{array}{c}13.90 \\
(21.77)\end{array}$ & $\begin{array}{c}26.21 \\
(30.76)\end{array}$ & 187.10 \\
\hline $\begin{array}{l}\text { Vermicompost }+ \\
\text { T. viride }\end{array}$ & 5 tons $+5 \mathrm{kgs}$ & $\begin{array}{c}28.88 \\
(32.47)\end{array}$ & $\begin{array}{c}53.33 \\
(46.42)\end{array}$ & $\begin{array}{c}18.32 \\
(25.22)\end{array}$ & $\begin{array}{c}34.66 \\
(35.99)\end{array}$ & 155.57 \\
\hline No amendments & - & $\begin{array}{c}48.88 \\
(44.36)\end{array}$ & $\begin{array}{c}75.55 \\
(60.73)\end{array}$ & $\begin{array}{c}32.26 \\
(34.58)\end{array}$ & $\begin{array}{c}53.97 \\
(47.31)\end{array}$ & 141.10 \\
\hline \multicolumn{2}{|c|}{ Mean } & $\begin{array}{c}30.55 \\
(33.34)\end{array}$ & $\begin{array}{c}54.72 \\
(47.85)\end{array}$ & $\begin{array}{c}20.21 \\
(26.45)\end{array}$ & $\begin{array}{c}35.56 \\
(36.41)\end{array}$ & \\
\hline \multicolumn{2}{|c|}{ S.Em+ } & 0.89 & 0.55 & 0.33 & 0.48 & 4.09 \\
\hline \multicolumn{2}{|c|}{$\mathrm{CD}(0.05 \%)$} & 1.57 & 1.33 & 0.70 & 1.01 & 9.34 \\
\hline
\end{tabular}

*Leaf blight incidence and intensity recorded at flowering (I) and 10 days before dehaulming (II) stages; data are mean of three replications.

Figures in parenthesis are arc sine transformed values

Table.4 Effect of soil amendments on tuber grades in 2017 cropping season

\begin{tabular}{|l|l|l|l|}
\hline & \multicolumn{3}{|c|}{$* *$ Tuber grade $(\%)$} \\
\hline Treatments & A & B & C \\
\hline Vermi-compost & 27.80 & 51.30 & $\mathbf{2 0 . 9 0}$ \\
\hline Farmyard Manure (FYM) & 31.06 & 50.96 & $\mathbf{1 7 . 9 5}$ \\
\hline Sheep Manure & 24.87 & 53.22 & $\mathbf{2 1 . 8 9}$ \\
\hline Trichoderma viride & 24.97 & 51.03 & $\mathbf{2 4 . 0 0}$ \\
\hline Vermicompost + FYM & 28.91 & 51.10 & $\mathbf{2 0 . 0 0}$ \\
\hline T. viride + FYM & 39.87 & 44.13 & $\mathbf{1 6 . 0 0}$ \\
\hline Vermicompost + T. viride & 23.46 & 54.49 & $\mathbf{2 2 . 0 0}$ \\
\hline No amendments & $\mathbf{2 0 . 2 4}$ & $\mathbf{3 7 . 7 9}$ & $\mathbf{4 1 . 9 7}$ \\
\hline
\end{tabular}

**Figures in parenthesis are per cent tuber grade 
There were corresponding yield gains with different soil amendments; amendments with T. viride + FYM exhibited maximum tuber yield of $187.10 \mathrm{q} / \mathrm{ha}$ followed by soil amendment with FYM alone 175.44 q/ha compared to only $141.10 \mathrm{q} / \mathrm{ha}$ obtained in unamended check plots. The proportion of $\mathrm{A}$ and $\mathrm{B}$ grade tubers were also more in amended soils than in un-amended soils. Amendments with $T$. viride + FYM resulted in maximum 39.87 per cent A grade tuber followed by amendments with FYM 31.06 per cent compared to 20.24 per cent A grade tubers obtained in un amended check(Table4). The soil amendments with $T$. viride + FYM exhibited least 16 per cent $\mathrm{C}$ grade followed by FYM $17.95 \%$ tubers compared to un-amended check $(41.97 \%)$.

Potato late blight pathogen thrives and proliferates underneath the soil, infecting and ultimately rotting the tubers under moist conditions. The movement of the pathogen zoospores and their spread under soils is known to largely depend on many soil factors (Porter, 2006). Therefore, besides exercising a check on pathogen activities above ground, the manipulation of soil conditions to the disadvantage of the pathogen is also believed to restrict the spread of the disease. Under the present studies, therefore, different nonchemical soil amendments made singly or in combination indicated that amendments with Trichoderma viride + FYM exhibited minimum late blight intensity of 25.90 and $26.21 \%$ compared to 47.93 and 53.97 obtained in unamended check during 2016 and 2017 respectively, resulting in proportionate yield gains. The use of $T$. viride and soil amendments with well decomposed compost for the control of many soil-borne pathogens, is well established. Several studies have shown that organic amendments are very effective in controlling diseases caused by pathogens such as Fusarium Spp., Pythium spp. Rhizoctonia solani, Sclerotinia spp.
Sclerotium spp, Thielaviopsis basicola and Verticillium dahlia (Veeken et al., 2005). Different complementary mechanism have been proposed to explain the suppressive capacity of organic amendments; enhanced activities of antagonistic microbes, increased competition against pathogens for resources that cause fungistasis, release of fungitoxic compounds during organic matter decomposition or induction of systemic resistance in the host plants (Tenuta and Lazarovits, 2002). Addition of FYM along with $T$. viride seems very useful for initial proliferation of the bio-agents. Formulation of $T$. viride significantly reduced $P$. infestans sporangial germination and has potential to control potato late blight under control condition (Shailbala and Amarendra Kumar, 2017). Active management of soil microbial communities is promising approach as a means to develop natural suppression of soilborne diseases and improve crop productivity (Garbeva et al., 2004).

The goal of this approach is to manipulate, alter, or augment the microbial characteristics of the soil through various management practices that increase soil microbial activity, diversity, population of plant-beneficial organism, and antagonism. The reduction in soil-borne diseases of potato with $T$. harzianum and $T$. virens has long been explored (Brewer and Larkin, 2005). The plants and plant products (organic amendments, crop residues, green manures) can dramatically affect soil microbial communities, and are primary drivers of soil microbial dynamics (Rashidul Islam et al., 2013) and thus may be important components in establishing and maintaining soil suppressiveness. With this present study it can be concluded that incorporation of organic soil amendments in the management of late blight disease is a promising feature which is as well eco-friendly in nature. 


\section{References}

Anonymous, 2004. Production recommendation for vegetables (Kashmir Division). Agriculture Technology Information Centre. Directorate of Extension Education. Sher-e-Kashmir University of Agricultural Sciences and Technology of Kashmir, p. 9.

Anonymous, 2015. $3^{\text {rd }}$ Advance Estimate of Area and Production of Horticulture Crops. Statistics and Market Information. National Horticulture Board, Ministry of Agriculture and Farmers Welfare Govt. Of India, Gurgaon, Haryana. (http//nhb.gov.in).

Brewer, M.T. and Larkin, R.P. 2005. Efficacy of several potential bio control organisms against Rhizoctonia solani on potato. Crop Protection 24: 939-950.

Garbeva, P., van Veen, J.A. and van Elsas, J.D. 2004. Microbial diversity in soil: selection of microbial populations by plant and soil type and implications for disease suppressiveness. Annual Review of Phytopathology 42: 243-270.

Mohan, C. and Thind, T.S. 1999. Resistance and relative performance of some new fungicides for active management of potato late blight in Punjab. Indian Journal of Mycology and Plant Pathology 29(1): 23-37.

Porter L.D., Cummings, T.F. and Johnson, D.A. 2006. Effects of Soil-Applied Late Blight Foliar Fungicides on Infection of Potato Tubers by Phytophthora infestans. Plant Disease 7: 694-698.

Rashidul Islam, M., Mandal, C., Hossain, I. and Meah, B. M. (2013). Organic management: An alternative to control late blight of potato and tomato caused by Phytophthora infestans. Int. J. Theoretical and Applied Sci., 5: 32-42.

Shailbala and Amarendra Kumar. 2017. Ecofriendly management of late blight of potato-A review. J. Appl. \& Nat. Sci. 9 (2): $821-835$.

Sundaresha, S., Kumar, S., Singh, B. P., Jeevalatha, A., Rawat, S., Mahota, A.K. and Sharma, T. R. (2015). Comparative genome analysis of Irish famine pathogen with Indian Phytophthora infestans isolate. In: 3rd International symposium on Phytophthora: Taxonomy, genomics, pathogenicity, resistance and disease management. 9th -12th September, 2015. Bengaluru, India, Pp. 24.

Tenuta, M. and Lazarovits, G. 2002. Ammonia and nitrous acid from nitrogenous amendments kill the micro sclerotia of Verticillium dahliae. Phytopathology 92: 255-264.

Veeken, A.H.M., Blok, W.J., Curci, F., Coenen, G.C.M., Temorshuizen, A.J. and Hamelers, H.V.M. 2005. Improving quality of composted bio waste to enhance disease suppressiveness of compost-amended, peat based potting mixes. Soil Biology and Biochemistry 37: 2131-2140.

Viswanath, H.S., K.A. Bhat, N.A. Bhat, T.A. Wani and Mohammad Najeeb Mughal. 2018. Antibacterial efficacy of aqueous plant extracts against storage soft rot of potato caused by Erwinia carotovora. Int.J.Curr.Microbiol.App. Sci. 7(01): 2630-2639.

\section{How to cite this article:}

Peerzada, S. H., K. A. Bhat and Viswanath, H. S. 2020. Studies on Management of Late Blight (Phytophthora infestans (Mont) de Bary) of Potato Using Organic Soil Amendments. Int.J.Curr.Microbiol.App.Sci. 9(02): 2093-2099. doi: https://doi.org/10.20546/ijcmas.2020.902.237 